\title{
APMIERINĀTĪBA AR DZĪVI UN G̦EOGRĀFISKĀ MOBILITĀTE: TEORĒTISKAIS IETVARS
}

\section{Lìga Feldmane, Elīna Apsīte-Beriña, Ģirts Burgmanis}

Latvijas Universitāte, G̣eogrāfijas un Zemes zinātṇu fakultāte,e-pasts:elina.apsite-berina@lu.Iv

\begin{abstract}
Anotācija. Rakstā aplūkots apmierinātības ar dzīvi jēdziens, kuru arvien vairāk izmanto kā nozīmīgu subjektîvās pašsajūtas jeb labjutes rādītāju dažādu zinātnuu virzienu pētījumos. Mūsdienās ǵeogrāfijā apmierinātības ar dz̄ivi vērtējums tiek lietots kā komplekss indikators, kas parāda dažāda mēroga teritoriju attīstības pakāpi daudz precīzāk nekā tradicionāli izmantotie ekonomiskie rādītāji. Plašais saistìto pētāmo jautājumu loks ǵeogrāfijā ḷauj skaidrot ne tikai sociālekonomisko attīstību, bet arī mobilitātes telpiskās likumsakarības. Tāpēc raksts veltīts iepriekšējo pētījumu apkopojumam par apmierinātību ar dzìvi, labjutību un dz̄ivesvietas maiṇu kā ǵeogrāfiskās mobilitātes sastāvdaḷu.
\end{abstract}

Atslēgas vārdi: geoogrāfiskā mobilitāte, apmierinātība ar dzīvi, dz̄ives kvalitāte, subjektīvā labjutība.

\section{Ievads}

Pēdējās četrās desmitgadēs pētījumu skaits par iedzīvotāju apmierinātību ar dz̄ivi (life satisfaction) vai līdzīgiem subjektīvās pašsajūtas rādītājiem - dzīves kvalitāte (quality of life), labjutība (well-being), laime (happiness) un labklājība (welfare) dažādās zinātṇu nozarēs ir strauji palielinājies (Realo, Dobewall 2011). Iemesls apmierinātības ar dzīvi starpdisciplināro pētījumu aktualitātes pieaugumam saistīts ar domas mainu teritorijas attīstības vērtěšanas pieejā. Ekonomisko rādītāju - IKP, iespējas attīstītajās valstīs kompleksi atspoguḷot teritorijas attīstības pakāpi, aizvien vairāk tiek apšaubītas (Proto, Rusticini 2013), apliecinot, ka mūsdienu sarežǵgitajā pasaulē vairs nepietiek ar vienkāršiem un viendimensionāliem indikatoriem, lai izdarītu vispārinošus secinājumus. 
Tā, piemēram, "Īsterlina paradokss" (Easterlin paradox) nosaka, ka teritorijās ar augstu IKP ne vienmēr iedz̄ivotāji būs laim̄̄gi un apmierināti ar dzīvi (Easterlin 1995).

G̣eogrāfijā pētījumi par apmierinātību ar dz̄ivi ir aktuāli, jo ne tikai atklāj noteiktas teritorijas iedzīvotāju vēlmi līdzdarboties sabiedriskajās aktivitātēs, sniegumu darba vietā, veselību, mūža ilgumu un ienākumu līmeni (Diener, Diener 2002, Lyubomirsky et al. 2005), bet arī l̦auj novērtēt veikto teritorijas plānošanas pasākumu un realizēto iniciatīvu efektivitāti (Marans 2002), izprast dzīvesvietas izvēles motivāciju (Golledge, Stimson 1987) un noteikt regiionālās migrācijas un attīstības telpiskās likumsakarības (Kemp et al. 1997). Latvijā iedzīvotāju subjektīvās pašsajūtas rādītāju un to ietekmes uz lēmumu pieṇemšanu pētījumu ǵeogrāfijā (piemēram, Bērziṇš, Krišjāne 2008), salīdzinot ar citām Eiropas valstīm, ir maz, tomēr to skaits strauji palielinās, apliecinot, ka šie starpdisciplinārie pētījumi ir aktuāli.

Latvijā atzīstamu tematisko pētījumu pēdējos gados ir veikusi Centrālā statistikas pārvalde, kas tāpat kā līdzīgos pētījumos Eiropā vērtējusi dzīves kvalitāti lielajās pilsētās (Dzīves kvalitāte pilsētās 2017). Pētījumā veiktajā aptaujā iekḷauti jautājumi par iedzīvotāju kopējo apmierinātîbu ar dzīvi, finansiālo stāvokli un dzīvesvietu. Līdz ar to arī Latvijā ir iespēja analizēt pašlaik ǵeogrāfijā aktuālus jautājumus. Rakstā tiks aplūkoti pašlaik aktuālie dzìves kvalitātes pētniecības jomas jēdzieni, to interpretācija teorētiskajā literatūrā, kā arī saistîba ar iepriekšējiem pētījumiem ǵeogrāfijas jomā, kas skar dzīvesvietas izvēli un iedzīvotāju migrāciju.

\section{Kas ir apmierinātība ar dz̄̄vi: jēdzieni un skaidrojumi}

Mūsdienās apmierinātība ar dzìvi tiek uzskatīta par vienojošu elementu citiem kontekstuāli līdzīgiem jēdzieniem: dzīves kvalitāte, laime un labjutība, kuru nozīmes savstarpēji pārklājas. Plašākā izpratnē apmierinātība ar dzīvi ir subjektīvās pašsajūtas rādītājs, kas ḷauj novērtēt cilvēka dzīves kvalitāti attiecībā pret izvirzīto kritēriju (Diener et al. 1985). Pētījumos, lai izmērītu apmierinātību ar dzīvi, lielākoties tiek izmantotas divas pieejas. Pirmā ietver ideju, ka labjutība ir dažādu savstarpēji saistītu cilvēka dzīves aspektu (ǵmene, darbs, veselība, utt.) novērtējumu kombinācija (Kau, Wang 1995). Otra pieeja uzsver cilvēka demogrāfisko rādītāju un materiālo vērtību nozīmi apmierinātībā ar dzīvi vērtējumā (Keng et al. 2000). Pētījumi pēdējos 40 gados dažādās valstīs apliecina, ka attīstītajās valstīs, lai gan auguši materiālie resursi uz vienu iedzīvotāju, nav mainījies apmierinātības ar dzīvi vērtējums (Easterlin 1995). Demogrāfs Ričards Īsterlins (Richard Easterlin), kura vārdā arī nosaukts jēdziens 'Īsterlina paradokss' (Easterlin 1974), pētot sakarību starp iedzīvotāju laimes sajūtu, apmierinātību ar dzīvi un ekonomiskajiem procesiem secināja, ka valsts IKP lielums nav saistīts ar lielāku iedz̄ivotāju laimes sajūtu. Lai gan iedzīvotāji ar augstākiem ienākumiem bieži ir laimīgāki, tomēr tas nenozīmē, ka, augot iedzīvotāju ienākumiem, palielināsies arī laimes sajūta. Ienākumu palielinājums rada jaunu materiālo vēlmju kāpumu, un līdz ar to apmierinātība ar savu labklājīibu nevairojas. (Easterlin 2001). Dzilāâu skaidrojumu minētajam paradoksam piedāvā psihologi, norādot, ka cilvēka uzmanība pārspīlēti saista vēlamo ienākumu palielinājumu ar laimi (Kahneman et al. 
2006). Lai arī ilgtermiņā apmierinātība ar dzīvi ir ciešāk saistīta ar veidu, kā tiek izmantots brīvais laiks, tomēr lielākā daḷa cilvēku ar augstiem ienākumiem to pavada strādājot. Līdz ar to lielāki ienākumi saistās arī ar augstāku stresa un spriedzes līmeni.

Dažāāās zinātnes nozarēs, pakāpeniski attīstoties pētījumu virzienam par cilvēku apmierinātību ar dzīvi, tiek izšķirti arī citi līdzịgi jēdzieni, kas pēc pētnieku domām precīzāk varētu konceptualizēt subjektīvas labjutības vērtējumu. No citiem biežāk pētījumos aplūkotajiem līdzīgajiem jēdzieniem jāmin laimes jēdziens (happiness), kuru pētījumos izmanto arvien biežāk. Turklāt strauji aug arī pētījumi par cilvēku laimes sajūtu, un dažos avotos pat tiek piedāvāta jauna zinātnes joma - zinātne par laimi (science of happiness), kuras mērḳis būtu izmērīt laimes sajūtu, identificēt tās galvenos ietekmējošos faktorus un noteikt to relatīvo nozīmību (Ballas, Tranmer 2012). Lai gan sākotnēji šis jēdziens daudzus desmitus gadu tika saistìts ar psiholoǵijas zinātni, pēdējos gados tas tiek aplūkots starpdisciplināros pētījumos psihologijāa, ekonomikā, sociologijīā, politikā, vadības zinātnē un arī geogrāfijā. Literatūrā (David et al. 2014) laime tiek raksturota (1) kā veselais saprāts, kas atspoguḷo indivīda labklājību vai (2) kā labjutības hedoniskais jeb prieka aspekts. Veenhovens (1991) laimi definējis kā stāvokli, kuru sasniedzot, indivīds vērtē savu kopējo apmierinātību ar dzīvi kā labvēlīgu. Viṇš laimes jēdzienu lieto kā sinonīmu apmierinātībai ar dzīvi un definē kā stāvokli, kad cilvēkam ir skaidrs dzīves novērtējums. Starp atpazīstamākiem laimes pētniekiem minams arī britu ekonomists Ričards Lajards (Richard Layard), kas turpinājis Īsterlina ideju par nemateriālo lietu ietekmi uz laimes sajūtu (Layard et al. 2006; Layard 2014), kā arī Freijs un Stucers (Frey, Stutzer 2002), kas arī plaši pētījuši laimes sajūtu ekonomikas disciplīnas perspektīvā.

Saskaṇā ar Pitaua un viņa kolēguu domām (Pittau etal. 2009), jēdziens apmierinātżba ar dzīvi (life satisfaction) nav tas pats, kas laime: tie abi ir saistīti ar personīgo jeb subjektīvo labjutību, tomēr būtu jāuztver kā dažādi jēdzieni. Pitau un viņa kolēǵi norāda, ka, uzdodot jautājumu, cik laimīgi ir cilvēki, tie visbiežāk iedomājas par gaistošu pašreizējā emocionālā stāvokḷa jēdzienu, kamēr apmierinātību ar dzīvi biežāk uztver kā vispārēju un daudz stabilāku dzīves uzplaukumu. Savukārt indivīda subjektīvā labjutība ietver abus: gan emocionālo, gan kognitīvo novērtējumu, un dažādi cilvēki to uztver atšķirīgi. Tas izskaidro, kādēl dažās valstīs apmierinātības pētījumos tiek novērota, piemēram, zema apmierinātība ar dzīvi, lai gan laimes sajūta tai pašā laikā ir augstā līmenī.

Jēdziens labjutība savukārt ir kā apvienojošs termins vairākiem jēdzieniem, kas saistīiti ar indivīda labsajūtu, un tas ietver arī tādu jēdzienu kā subjektīvā labjutība (subjective well-being, citur lietots arī kā individual well-being) (David et al. 2014; Ballas, Tranmer 2012). Subjektīiva labjutība tiek skaidrota kā lietderības funkcijas faktori, kas var tikt izmērīti (piemēram, patēriņš, algas un nomas maksas, apbūves zeme, vietējās êrtības) un kurus pieṇemts saistīt ar dzīves kvalitāti (Ballas, Tranmer 2012).

\section{G̣eogrāfiskā mobilitāte un apmierinātība ar dzīvi}

G̣eogrāfijā apmierinātības ar dzīvi jēdziens galvenokārt saistīts ar dzīves kvalitātes, dzīvesvietas izvēles un migrācijas pētījumiem. Pētījumos pilsētu geogrāfijā aizvien plašāk 
tiek aplūkots dzīves kvalitātes jēdziens. Dzīves kvalitāte ir komplekss jēdziens, kuru veido katra cilvēka individuāls subjektīvs un objektīvs skatîjums uz cilvēka, dabas un kultūras veidoto vidi dažādos mājokḷa, apkaimes u.c. mērogos (Stimson, Marans 2011). Diskusijās par teritorijas dzīves kvalitātes vērtējumu kā subjektīvās labjutības indikatoru plaši tiek apspriests tā saturs. Līdz šim pētniekiem nav izdevies rast vienotu viedokli par indikatora saturu. Dzīves kvalitātes indikatoram jāietver objektīvie (sekundāri dati par noziedzības, sabiedriskā transporta sistēmas u.c. teritoriju raksturojošiem lielumiem) un subjektīvie rādītāji (teritorijas dzīves vides un pieejamo ērtību novērtējums).

Vairāki autori savos pētījumos atklājuši sakarības starp dzīvesvietu un iedzīvotāja apmierinātību ar dzīvi kopumā. Piemēram, iedz̄ivotāju aptauja Eiropas valstīs liecina, ka pastāv atšķirība starp apmierinātību ar dzīvi valstu un reǵionu starpā (Pittau et al. 2010). Ziemeḷeiropas valstīs, piemēram, Dānijā, Zviedrijāa, Lielbritānijā, Īrijā un Somijāa, iedzīvotāju apmierinātības līmenis ir stabilāks un konstanti augstāks, savukārt Dienvideiropas valstīs - Spānijā, Portugālē, Itālijāa, Grieḳijā - tas ir zemāks. Lai arī pētījumā tika analizēti dažādi reǵionu individuālie un dažādi ieņēmumu un nodarbinātības līmeni raksturojošie rādīiāji, tomēr tika atklāts, ka pastāv arī neizskaidrojama reǵionālā līmeņa ietekme uz apmierinātîbu ar dzīvi. Tas apliecina, ka ǵeogrāfiskā vieta ir jāṇem vērā kā iedzīvotāju apmierinātības ar dzīves līmeni ietekmējošs faktors. Turklāt tika noskaidrots, ka nabadzīgajās valstīs un reǵionos apmierinātība ar dzīvi ir vairāk saistīta ar ekonomiskiem faktoriem, turpretim bagātajos regiionos vairāk saistîta ar nemateriālajām vērtībām jeb 'kultūras' faktoru. (Pittau et al. 2010)

Balla un Tranmers (Ballas, Tranmer 2012) pētījumā par iedzīvotāju laimes un labjutības sajūtu Lielbritānijā noskaidrojuši, ka iedzīvotāji, kas dzīvo pašreizējā dzīvesvietas adresē vairāk nekā 5 gadus, kopējo labjutību novērtējuši augstāk par vidējo, salīdzinot ar iedzīvotājiem, kas dzīvesvietā dzīvo mazāk par gadu. Pēc pētnieku domām, minētie rezultāti norāda uz to, ka persona jūtas labāk un savu dzīvi vērtē labāk, ja ir dzīvojusi konkrētajā dzīvesvietā ilgāku laiku un izveidojusi ap sevi plašu sociālo tīklu. Tāpat daļai cilvēku labjutība tomēr ir saistīta arī ar finansiālu stabilitāti un labklājību. Minētajā pêtījumā tika noskaidrots, ka cilvēki, kas savu mājokli nomā no privāta īpašnieka vai vietējās varas iestādēm, savu labjutības līmeni vērtē zemāk nekā personas, kam mājoklis ir īpašumā, savukārt faktors, ka mājoklis ir īpašumā, pozitīvi ietekmē personas laimes sajūtu. Pētījumā tika secināts, ka laimes sajūtu ietekmē cilvēki, kas dzīvo konkrētajā teritorijā, nevis teritorija pati par sevi.

Pēdējos gados, augot starptautiskās un iekšzemes migrācijas apjomam, viens no nozīmīgākajiem virzieniem subjektīvās pašsajūtas pētījumos ir ǵeogrāfiskās mobilitātes un apmierinātības ar dzīvi saiknes izpēte. Līdzīgi kā teritorijas attīstības novērtējumā arī migrācijas motīvu pētījumos tādi teritorijas ekonomiskās aktivitātes rādītāji kā darba vietu skaits un atalgojuma līmenis ne vienmēr spēj izskaidrot iedzīvotāju pārvietošanās cēloṇus starp valstīm vai apdzīvotajām vietām. Pētījumi attīstītajās valstīs liecina, ka daudz lielāka nozīme motivācijā migrēt un izvēlēties dzīvesvietu var būt pieejamo ērtību (amenities) un kopējās dzīves kvalitātes atškirības teritorijās (Ferguson et al. 2007, Hamm et al. 2017). N̦emot vērā straujo tehnikas attīstību, mūsdienās cilvēkiem, kas 
vēlas uzlabot savu dzīves kvalitāti, ir relatīvi viegli mainīt dzīvesvietu. Dzīvesvietas maiņa bieži ir saistīta ar ekonomiskiem faktoriem un izmaksu - ieguvumu analīzi, kuras pamatā ir vēlme uzlabot savu dzīves līmeni, labklājību. (Switek 2016). Tomēr daži pētnieki uzskata, ka cilvēki nevar uzlabot savu labjutību, tikai mainot dzīvesvietu (Ballas, Tranmer 2012, citēts Hoehn et al. 1987).

Pētījumā Lielbritānijā noskaidrots, ka dzīvesvietas maiņa izraisa cilvēkā laimes sajūtu (Nowok et al. 2013). Turklāt īpaši aktuāli tas ir gadā, kad notiek pārcelšanās uz jaunu mājokli, jo iedzīvotāji migrē galvenokārt, lai uzlabotu savus dz̄ives apstākḷus (ne vienmēr ekonomiskie iemesli). Līdz ar to dzīvesvietas maiņa rada īslaicīgu laimes sajūtu un pēc gada subjektīvais pašsajūtas vērtējums mazinās, atgriežoties iepriekšējā līmen̄i. Līdzīgus rezultātus parāda arī pêtījumi Ķīnā un Amerikas Savienotajās Valstīs (Knight, Gunatilaka 2010; Bartram 2011). Savukārt tie, kas maina dzīvesvietu vairākas reizes, ir nelaimīgāki par tiem, kas migrē tikai vienu reizi. Bez tam migrācija lielos attālumos sniedz līdzīgu laimes sajūtu, kā migrācija nelielā attālumā, lai gan pārcelšanās un iedzīvošanās izmaksas jaunajā dzīvesvietā ir augstākas. Pêtījumos, kuros salīdzināta apmierinātība ar dzīvi starp Austrumeiropas migrantiem, kuri pārcēlušies uz Rietumeiropas valstīm un tiem, kuri palikuši dzimtenē, konstatêts, ka laimīgāki ir tie, kuri pametuši dzimteni (Bartram 2013). Lielākoties tas tiek saistīts ar to, ka laimes sajūtu ietekmējusi dzīvesvietas maiṇa. Tāpat novērots, ka pastāv ievērojamas atšķirības starp etniskajām grupām, piemēram, migranti no Krievijas, Turcijas un Rumānijas ir laimīgāki par dzimtenē palikušajiem, kamēr migranti no Polijas ir ievērojami mazāk laimīgi par palicējiem.

Pētījumā par Zviedrijas jauniešu iekšzemes migrāciju tika atklāts, ka migrācija kopumā rada pozitīvas pārmaiṇas uz iedzīvotāju apmierinātību ar dzīvi (Switek 2016). Turklāt apmierinātības ar dzīvi noturība ir atkarīga no tā, kāds bijis personas mērkị mainot dz̄ivesvietu. Laika posmā, kas ilgst no brīža, kad mainīta dzīvesvieta līdz 6 gadiem, apmierinātība ar dzīvi aug gan personām, kuras migrējušas darba dēl, gan migrantiem, kuri to darījuši ar darbu nesaistītu apstākḷu dẹl. Savukārt ilgākā laika periodā no 6 līdz 10 gadiem - nozīmīgs palielinājums apmierinātībā ar dzīvi novērots tikai personām, kuras pārcēlušās darba dēḷ.

Vairāki pēdējos gados veikti pētījumi Eiropas valstīs (Betz, Simson 2013; Ivlevs, Veliziotis 2017; Akay et al. 2014) apliecina, ka pretēji visbiežāk negatīvajai attieksmei pret migrantiem, imigrācijas plūsma rada pozit̄̄vu efektu vietējo iedzīvotāju apmierinātībā ar dz̄ivi, subjektīvo labjutību un laimes sajūtu. Pētījumā Vācijā (Akay et al. 2014) tika noskaidrots, ka imigrācija būtiski pozitīvu ietekmi uz apmierinātību ar dzīvi izraisīja gados jaunajos un vidēja vecuma vietējos iedzīvotājos. Citā pētījumā Anglijā (Ivlevs, Veliziotis 2017) atklāja, ka imigrācijas rezultātā apmierinātība ar dzìvi palielinājās mājsaimniecībās ar augstākiem ienākumiem, savukārt samazinājās mājsaimniecībās ar zemākiem ienākumiem. Gados vecākiem iedzīvotājiem un iedzīvotājiem ar zemākiem ienākumiem iebraucēji pastiprināja konkurenci darba tirgū, līdz ar to samazinot iespējas iegūt zemākās kvalifikācijas darbus. Tāpat nevar nešaubīgi apgalvot, ka visi vietējie iedzīvotāji ir apmierināti ar imigrantu pieplūdumu un apkārtnes 
iedzīvotāju etniskās daudzveidības palielināšanos. Kā noskaidrots Lielbritānijāa (Longhi 2014), baltādainie briti, kas dzīvo teritorijās, kurās ir liela etniskā daudzveidība, kopumā ar dz̄ivi ir mazāk apmierināti, nekā tie, kuru dzīvesvietās etniskā daudzveid̄̄ba ir zema. Starp iebraucējiem un melnādainajiem britu tautības pārstāvjiem minētā sakarība netika novērota. Migrācija ietekmē ne tikai pārmaiņas migranta apmierinātībā ar dzīvi, bet arī palicēju laimes sajūtu un apmierinātību ar dzīvi.

\section{Izmantotā literatūra}

Akay, A., Constant A., Giulietti, C. (2014). The impact of immigration on the well-being of natives. Journal of Economic Behavior and Organization, 103, 72 - 92.

Aslam, A., Corrado, L. (2012). The geography of well-being. Journal of Economic Geography, $12,627-649$.

Ballas, D., Tranmer, M. (2012). Happy People or Happy Places? A Multilevel Modeling Approach to the Analysis of Happiness and Well-Being. International Regional Science Review, 35(I), 70 - 102.

Bartram., D. (2011). Economic migration and happiness: Comparing immigrants' and natives' happiness gains from income. Social Indicators Research,103, $57-76$.

Bartram., D. (2013). Happiness and 'economic migration': A comparison of Eastern European migrants and stayers. Migration Studies, 1(2), 156 -175.

Betz, W., Simson, N.B. (2013). The effects of international migration on the well-being of native populations in Europe. IZA Journal of Migration, 2(1), 12.

Bērziñš, M., Krišjāne, Z. (2008). Amenity migration in post-socialist metropolis: the case of Rīga agglomeration. Proceedings of the Latvian Academy of Sciences, 62B (1/2), 71-77.

Diener, E. D., Emmons, R. A., Larsen, R. J., Griffin, S. (1985). The satisfaction with life scale. Journal of personality assessment, 49(1), $71-75$.

Diener, E., Biswas-Diener, R. (2002). Will money increase subjective well-being? Social indicators research, 57(2), $119-169$.

Dzīves kvalitāte pilsētās. (2017). Centrālā Statistikas Pārvalde: http://www.csb.gov.lv/respondentiem/dzives-kvalitate-pilsetas-45725.html (20.01.2018)

Easterlin, R. (1974). Does Economic Growth Improve the Human Lot? Some Empirical Evidence. In David, P.A. and Reder, M.W. Nations and Households in Economic Growth: Essays in Honor of Moses Abramovitz. New York: Academic Press, Inc.

Easterlin, R. (2001). Income and happiness: towards a unified theory. The Economic Journal, 111, $465-484$.

Easterlin, R. A. (1995). Will raising the incomes of all increase the happiness of all? Journal of Economic Behavior \& Organization, 27(1), 35 - 47.

Frey, B.S., Stutzer, A. (2002). What Can Economists Learn from Happiness Research? Journal of Economic Literature, 40(2), $402-435$.

Golledge, R. G., Stimson, R. J. (1987). Analytical behavioural geography. London: Croom Helm.

Ivlevs, A., Veliziotis, M. (2017). Local-level immigration and life satisfaction: The EU enlargement expierence in England and Wales. Environment and Planning A, 50(1), 1 - 19.

Kahneman, D., Krueger, A. B., Schkade, D., Schwarz, N., Stone, A. A. (2006). Would you be happier if you were richer? A focusing illusion. Science, 312(5782), 1908 - 1910.

Kemp, D., Manicaros, M., Mullins, P., Simpson, R., Stimson, R., Western, J. (1997). Urban metabolism: A framework for evaluating the viability, livability and sustainability of South East Queensland. Brisbane: The Australian Housing and Urban Research Institute.

Keng, K. A., Jung, K., Jiuan, T. S., Wirtz, J. (2000). The influence of materialistic inclination on values, life satisfaction and aspirations: An empirical analysis. Social Indicators Research, 49(3), 317- 333.

Knight., J., Gunatilaka, R. (2010). Great Expectations? The Subjective Well-being of Rural-Urban Migrants in China. World Development, 38(1), 113-124. 
Layard, R. (2006). Happiness and public policy: A challenge to the profession. Economic Journal, 116(510), C24 - C33.

Layard, R., Clark, A.E., Cornaglia, F., Powdthavee, N., Vernoit, J. (2014). What predicts a successful life? A life-course model of well-being. Economic Journal, 124(580), F720 - F738.

Longhi, S. (2014). Cultural diversity and subjective well-being. IZA Journal of Migration, 3(1), 13.

Lyubomirsky, S., King, L., Diener, E. (2005). The benefits of frequent positive affect: Does happiness lead to success? Psychological Bulletin, 131(6), 803-855.

Marans, R. W. (2002). Understanding environmental quality through quality of life studies: The 2001 DAS and its use of subjective and objective indicators, Landscape and Urban Planning, 991, 1-11.

Marans, R. W., Stimson, R. (2011). An overview of quality of urban life. In Marans, R. W. and Stimson, R. (eds.). Investigating quality of urban life. Dordrecht: Springer, 1 - 29.

Nowok, B., van Ham, M., Findlay A.M., Gayle, V. (2013). Does migration make you happy? A longitudinal study of internal migration and subjective well-being. Environment and Planning, 45, 986-1002.

Pittau, M.G., Zelli, R., Gelman, A. (2010). Economic Disparities and Life Satisfaction in European Regions. Springer. Social Indicators Research, 96, 339 - 361.

Realo, A., Dobewall, H. (2011). Does life satisfaction change with age? A comparison of Estonia, Finland, Latvia, and Sweden. Journal of Research in Personality, 45(3), 297 - 308.

Susan A. D., Boniwell I., Ayers, A.C. (2014). The Oxford Handbook of Happiness. Croydon: Oxford University Press

Switek, M. (2016). Internal Migration and Life Satisfaction: Well-Being Paths of Young Adult Migrants. Social Indicators Research, 125,191 - 241.

Veenhoven, R. (1991). Is happiness relative? Social Indicators Research, 24(1), 1-34.

\section{Summary}

Paper is devoted to life satisfaction which increasingly is used as important indicator for subjective wellbeing researches in various fields. Currently life satisfaction in geography is used as complex indicator, which shows level of territorial development more precise than traditionally used economic indicators. Wide field of related research questions in geography allow explanations not only to socioeconomic development, but also spatial regularities of mobility. Thus this paper seeks to provide research overview on life satisfaction, well -being and relocation as part of geographic mobility. 